\title{
Nutritional Composition and Growth Performance of Fish Meal Supplemented with Sesame indicum (Beni Seed) in the Diets of Clarias gariepinus
}

\author{
${ }^{* 1}$ YAKUBU, N; ${ }^{2}$ ISAH, MC; ${ }^{3}$ MUSA, AI \\ ${ }^{l}$ Department of Biochemistry, ${ }^{2}$ Department of Biological Sciences, ${ }^{3}$ Department of Microbiology, Ibrahim Badamasi Babangida University, \\ Lapai, Niger State, Nigeria \\ *Corresponding Author Email: yndatsu2011@gmail.com; Tel: +2348065940069
}

\begin{abstract}
This study analyzed the chemical compositions, growth performance and nutrient efficiency of fish meal supplemented with varying percentage of $S$. indicum). A total of 150 of $C$. gariepinus fingerlings were grouped into 6 tanks with 20 C. gariepinus per tank. Each tank of fish was served with prepared fish meals supplemented with various levels of beniseed ( $S$. indicum), namely, DT1 (commercial diet), stand as the control group, DT2 $(0 \%$ beniseed with $100 \%$ soya bean meal, DT3 (25\% beniseed with $75 \%$ soya bean meal, DT4 $(50 \%$ beniseed with $50 \%$ soya bean, DT5 (75\% beniseed with $25 \%$ soya bean and DT6 (100\% beniseed with $0 \%$ soya bean, individually. Chemical compositions of each experimental diet and fish carcass were determined and the feed utilization by fishes was equally monitored and calculated. Higher levels of moisture content $(7.42 \%)$, crude fiber (4.24\%), total ash $(3.16 \%)$, crude protein and fat $(29.21$ and $30.01 \%)$ and carbohydrate $(27.21 \%)$ were established for the dietary group (DT6) as compared to other dietary groups. In contrast, the fish carcass moisture, crude fiber, and total ash contents were high in fish fed DT4 and DT2 compared to others. Elevated calcium (760.7 and 763.6 $\mathrm{mg} / 100 \mathrm{~g}$ ), phosphorus (683.4 and $685.1 \mathrm{mg} / 100 \mathrm{~g})$, sodium (302.4 and $303.4 \mathrm{mg} / 100 \mathrm{~g}$ ), potassium $(820.6$ and 825 $\mathrm{mg} / 100 \mathrm{~g})$ and iron $(32.67$ and $37.31 \mathrm{mg} / 100 \mathrm{~g})$ contents were noted in DT5 and DT6 than the other diets. The fish carcass fed DT6 were richer in calcium $(803 \mathrm{mg} / 100 \mathrm{~g})$, phosphorus $(5023 \mathrm{mg} / 100 \mathrm{~g})$, sodium $(492 \mathrm{mg} / 100 \mathrm{~g})$, potassium $(6313 \mathrm{mg} / 100 \mathrm{~g})$ and iron $(5.12 \mathrm{mg} / 100 \mathrm{~g})$ than the others. C. gariepinus fed DT6 recorded high weight gains $(45.64 \mathrm{mg})$ while fish DT4 had a value of length gain $(1.80 \mathrm{~cm})$. Higher significant values were observed for SGR $(54.33 \%)$, PER $(2.47 \%)$, FI $(2.85 \%)$ and SR $(80.23 \%)$ as feed utilization in fish fed DT6. However, experimental diets (DT5 and DT6) with 75 and $100 \%$ S. indicum inclusion look promising and would enhance adequate growth performance and nutrient utilization of $C$. gariepinus, which may be used for the development of the product in various food industries.
\end{abstract}

\section{DOI: https://dx.doi.org/10.4314/jasem.v24i5.2}

Copyright: Copyright $(\mathrm{C} 2020$ Yakubu et al. This is an open access article distributed under the Creative Commons Attribution License (CCL), which permits unrestricted use, distribution, and reproduction in any medium, provided the original work is properly cited.

Dates: Received: 02 February 2020; Revised: 04 April 2020; Accepted: 11 May 2020

Keywords: C. gariepinus, fish meal, feed efficiency, growth performance, S. indicum.

Many wild plant products or seeds are been exploited as foods because of their adequate amount of nutrients provided to the inhabitants (Garbia et al., 2000, Peters et al., 2016). Sesamum indicum L. is a class of Pedaliaceae family of plants and it is found majorly cultivated in countries like the USA, India, China, Burma, Sudan and Nigeria (Garbia et al., 2000). It has a high content of oil, and protein and mineral (calcium) and been very good food for ages (Alobo, 2001). The fried and fermented seeds are used in making soup for human consumption (Uaboi et al., 2008). Sesame is a good healthy food additive controlling diseases and enhancing wellbeing. It's used to prevent cancer and heart disease (myristic acid) and its consumption reported to increase plasma gamma-tocopherol and promoted a vitamin E activity which is used to prevent cancer and disease of the heart (Conney et al., 2001). Beni seed has been loudly used as a protein supplement in the diet of fishes due to its digestible nutritional contents, favorable growth performance and feed utilization (Peters et al., 2016, Adeniyan et al., 2013). Fisheries displayed a vital role in enhancing the food security status of the people. It contributes about $15-16 \%$ to the total animal protein consumed by 2.9 billion people in low-income and food-deficient countries (Ayoola, 2010). About 520 million people, which is almost $8 \%$ of the world population have been estimated to depend majorly on income from fisheries for sustenance. A good protein ingredient in fish farming feed is the fishmeal and contributes significantly to the variable production cost in the aquaculture industry. However, decreasing fishmeal supply relative to demand and increasing costs threaten the sustainability and growth of the aquaculture industry (Ayoola, 2010). Dietary protein is described as the building block nutrient of the body and is given the most prominent consideration in the formulation of fish feeds. Lack of good quality feed 
for economic production adversely affects growth rates, disease manifestation and the total harvest of fish (Alatise et al., 2006). The success of fish farming invariably depends on the provision of suitable and economical fish feed (Effiong et al., 2019). The development of a more suitable aquaculture feed production will depend on identifying and establishing alternative feedstuffs to fishmeal (Idowu and Afolayan, 2013). This research considered the inclusion of Sesame indicum (Beni seed) powder as a source of proteins and antioxidants. The Beni seed also has the double advantage of serving as a source of mineral and vitamins. High proteinous fish meals have reported provide health and wellness of fish that could be related in terms of length and weight increases (Keke and Anene, 2011) as well as growth performances (Effiong et al., 2014). Past studies have demonstrated that complete or partial substitution of fishmeal with alternative proteins does not adversely affect fish performance (Ayoola, 2010). Hence, by promoting the inclusion of locally available proteinrich crops in fish meals may increase the fish production performance. Therefore, chemical composition analysis of fishmeal will enhance fish cultivation by improving fish growth performance and the elimination of stress and disease conditions that might affect product performance. This study was therefore carried out to evaluate the nutritional composition and growth performance of fish meal supplemented with Sesame indicum (Beni Seed) in the diet of Clarias gariepinus.

\section{MATERIALS AND METHODS}

Sample Collection: The sesame seed, maize, fish meal, groundnut cake, vitamin premix, Sodium Chloride common salt, Soya bean, and the experimental tank were collected at Lapai main market, Niger state in June 2019. Botanical identity was confirmed at the Department of Biological Sciences, Ibrahim Badamasi Babangida University, Lapai, Niger State.

Sample Preparation: The feedstuffs were finely grounded and mixed in the plastic bowl into dough form using hot water, with cassava starch as binding material. The mixture was then pelleted by passing it through a mincer of $2 \mathrm{~mm}$ die to produce a $2 \mathrm{~mm}$ diameter size of pellets. These were sundried to about $10 \%$ moisture content, packed in polythene bags and kept safe dry for use. The soya bean meal consisted of fish meal, soya bean, maize and other ingredients as presented in table 1. Feed formulation: Briefly, about six (6) experimental diets at varying sesame seed and soya beans meal compositions, namely, diet 1, 2, 3, 4, 5 and 6 were formulated (Table 2). The diet 1 is composed of $25 \%$ sesame seed meal with $75 \%$ soya bean meal, Diet 2 is composed of $50 \%$ sesame seed meal with $50 \%$ soya bean meal, Diet 3 is composed of $75 \%$ sesame seed meal with $25 \%$ soya bean meal, Diet 4 is $100 \%$ sesame seed meal with $0 \%$ soya bean meal, Diet 5 is $0 \%$ sesame seed meal with $100 \%$ soya bean meal and commercial feed was used as control.

\begin{tabular}{|c|c|c|c|c|c|c|}
\hline \multicolumn{3}{|c|}{ Ingredients } & \multicolumn{4}{|c|}{ Combination (\%) } \\
\hline \multicolumn{3}{|c|}{ Soya beans } & \multicolumn{4}{|c|}{48.4} \\
\hline \multicolumn{3}{|c|}{ Fish meal } & \multicolumn{4}{|c|}{21.5} \\
\hline \multicolumn{3}{|c|}{ Maize } & \multicolumn{4}{|c|}{11.4} \\
\hline \multicolumn{3}{|c|}{ Groundnut cake } & \multicolumn{4}{|c|}{15.2} \\
\hline \multicolumn{3}{|c|}{ Vitamin premix } & \multicolumn{4}{|c|}{1.3} \\
\hline \multicolumn{3}{|c|}{ Sodium chloride } & \multicolumn{4}{|c|}{2.2} \\
\hline \multicolumn{3}{|l|}{ Total } & \multicolumn{4}{|c|}{100} \\
\hline \multirow{3}{*}{ DT } & \multicolumn{5}{|c|}{ Table 2. Experimental diet formulation } & Dietary Treatment (\%) \\
\hline & DT 1 & DT & DT & DT & DT & DT \\
\hline & 011 & 2 & 3 & 4 & 5 & 6 \\
\hline $\begin{array}{l}\text { Sesame } \\
\text { seed }\end{array}$ & \multirow{2}{*}{$\mathrm{CD}$} & 0 & 25 & 50 & 75 & $\begin{array}{l}10 \\
0 \\
\end{array}$ \\
\hline $\begin{array}{l}\text { Soya bean } \\
\text { meal }\end{array}$ & & 100 & 75 & 50 & 25 & 0 \\
\hline
\end{tabular}

Animals: A total of one hundred and fifty of Catfish fingerlings ( $C$. gariepinus) of mixed-sex and the same age (mean weight of $4.5 \pm 0.20 \mathrm{~g}$ ) were purchased from Lapai Gwari fish Village, along Lapai - Paiko-Minna road, Niger state. The fishes were transported in an aerated aquarium into the department of Biology, Ibrahim Badamasi Babangida University, Lapai, Niger State. Fishes were allowed to acclimatize to experimental conditions for one week before the feeding trial and were fed commercial fish feed meal ( $2 \mathrm{mmVital}$ feed, company, and country) three times daily. After the acclimatization, the fishes were starved for 24 hours and the average weight and length of all fish in each rearing tank was taken as initial average weight and length. The water temperature, $\mathrm{pH}$ level, hardness of water and available oxygen of the aquarium were monitored throughout the experimental period. The leftover feed in the aquarium water was siphoned every day to avoid infections and mortality during the period of the experiment.

Experimental treatment and design: The total of a hundred and fifty of $C$. gariepinus fingerlings obtained was selected randomly into six (6) rearing tanks with 20 fingerlings of $C$. gariepinus per rearing tank (Kumar et al., 2011). Each rearing tank (T1, T2, T3, T4, T5, and T6) was assigned to an experimental diet as shown below, and all were replicated three (3) times and covered with a net to prevent the predators. The feeding trial commences after fish were starved for 24 hours before the introduction of experimental diet to each rearing tank at the varying percentage of sesame 
seed and soya beans meals inclusion; DT1 was served commercial diet only, DT2 was served with 0 and $100 \%$ of sesame seed meal and soya beans meal, DT3 was served with 25 and $75 \%$ of sesame seed meal and soya beans meal, DT4 was served with 50 and $50 \%$ of sesame seed meal and soya beans meal, DT5 was served with 75 and $25 \%$ of sesame seed meal and soya beans meal, and DT6 was served with 100 and $0 \%$ of sesame seed meal and soya beans meal, respectively. The fishes were fed with the experimental diet two times a day at $4 \%$ of the bodyweight for twelve (12) weeks. An electric weighing balance model of Shanghai Jingtian J72101N was used to weigh the fishes and total length was also measured every week. The growth and nutrient utilization were computed and the weight gained, length increased, mortality was observed and recorded. The samples of the experimental feed and the fish carcass were subjected to proximate analysis (AOAC, 2004). At the end of the experiment, the growth and nutrient utilization parameters were computed for fishes on each diet using the appropriate formulae as follow;

$$
\% \text { Fish SR }=\frac{\text { Total fish survived }}{\text { Total fish used }} \times 100
$$

Where Fish $\mathrm{SR}=$ fish survival rate

$$
\% \mathrm{WG}=\frac{\mathrm{W}_{f}-W_{i}}{\mathrm{~T}} \times 100
$$

Where $\mathrm{WG}=$ weight gain, $\mathrm{W}_{\mathrm{I}}=$ Initial weight, $\mathrm{W}_{\mathrm{f}}=$ Final weight, $\mathrm{T}=$ Time taken

$$
\% \mathrm{SWR}=\frac{\log \mathrm{W}_{f}-\log W_{i}}{\mathrm{~T}} \times 100
$$

Where $\mathrm{SWR}=$ Specific growth rate, $\mathrm{W}_{\mathrm{i}}=$ Initial weight, $\mathrm{W}_{\mathrm{f}}=$ Final weight, $\mathrm{T}=$ Time taken, $\log =$ Natural logarithm

$$
\mathrm{FI}=\frac{\text { Total weight gain }(\mathrm{g})}{\text { Number of survived fish }}
$$

Where FI = feed intake

$$
\mathrm{FCR}=\frac{\text { Total food given }(\mathrm{g})}{\text { Total weight gain }(\mathrm{g})}
$$

Where FCR $=$ feed conversion ratio

The proximate analysis of experimental diets and the animal carcass was analyzed following the standard method (AOAC, 2004). Moisture content was determined by oven-drying to a constant weight, crude fat and protein were determined using soxhlet extraction and micro - Kjeldahl method, respectively. Total ash and crude fiber were analyzed using muffle furnace combustion and trichloroacetic acid method, respectively. The carbohydrate was determined by 100 $-(\%$ moisture $+\%$ ash $+\%$ fat $+\%$ protein $+\%$ fiber $)$ (Henken et al., 1986, Blain, 2002, Effiong et al., 2019). The macro minerals (calcium, phosphorus, sodium, and potassium) contents of experimental diets and fish carcass were determined using standard methods of the French Association for Standardization, AFNOR (1977). The method of photometric absorption by AFNOR (1984) was used to determined calcium, sodium and potassium while the method of spectrophotometric absorption was used to analyzed total phosphorus and iron (AFNOR, 1984).

Statistical analysis: The data recorded were presented as the mean+standard deviation. Data were analyzed using one-way analysis of variance (ANOVA). Differences were considered statistically significant at $\mathrm{P}<0.05$ (Zar, 1996).

\section{RESULTS AND DISCUSSION}

The nutritional constituents of dietary treatment and that of the fish carcass both before to and after the introduction of dietary treatment are presented in Tables 3 and 4, respectively. The results revealed that the nutrient composition of all dietary groups was virtual different significantly $(\mathrm{p}<0.05)$ when compared to DT1 (control). A significant increased $(p<0.05)$ in the moisture content $(7.42 \%)$, crude fiber $(4.24 \%)$, total ash $(3.16 \%)$, crude protein and fat $(29.21$ and $30.01 \%$ ), and carbohydrate $(27.21 \%$ ) were established for the dietary group (DT6) as compared to other dietary groups (Table 3). High levels of moisture content observed in all experimental diets than that of DT1 (control) may signify the proportion and interaction of blend. The quality of foods may greatly depend on the moisture and water activity of the product (Peters et al., 2016). Again, the fat content in all diets elevated with increasing levels of beniseed inclusion. It may probably imply the oil nature of beniseed meal added. The shelf life of meal products is determined significantly with fat; therefore, high content of fat could be relatively not desirable in fish meal products. Rancidity in foods is promoted by fat that may develop some compounds with unpleasant smelling (Peters et al., 2016; Ihekoronye and Ngoddy, 1985). The high amount of total ash and crude fiber contents in all treatment diets compared to the control diet imply that all treatment diets are high in minerals and beneficial as it may be vital in the system of gastrointestinal health and metabolism in animals (Ragone, 1997). The findings of crude fat, fiber and total ash established in this study were somehow lower than the report of Olapade and George (2019). A significant increase in protein values observed in experimental diets than in DT1 (control) could be 
probably due to the vary percentage inclusion of $S$. indicum seed. These findings obtained in respect of all diets were lower significantly with what was demonstrated by Olapade and George (2019). Good numbers of amino acids are demonstrated in beniseed (Peters et al., 2016, 21). Peters et al. (2016) reported that these amino acids have 62 and $54 \%$ as the chemical score and net protein utilization, respectively, which imply a significant constituent that determines the quality properties of the fish meal. Therefore, a significant supply of quality protein may be expected from all the experimental diets to the fish body.

Table 3. Proximate analysis of nutrient constituent of the graded levels of the dietary treatments

\begin{tabular}{lllllll}
\hline \multirow{2}{*}{ DC (\%) } & \multicolumn{5}{c}{ Dietary treatments } \\
\cline { 2 - 6 } & DT1 & DT2 & DT3 & DT4 & DT5 & DT6 \\
\hline MC & $2.50 \pm 0.01^{\mathrm{b}}$ & $2.54 \pm 0.001^{\mathrm{b}}$ & $2.58 \pm 1.00^{\mathrm{b}}$ & $2.56 \pm 1.20^{\mathrm{b}}$ & $4.50 \pm 0.01^{\mathrm{b}}$ & $7.42 \pm 0.10^{\mathrm{a}}$ \\
CFi & $1.20 \pm 1.00^{\mathrm{f}}$ & $2.57 \pm 0.01^{\mathrm{e}}$ & $2.70 \pm 0.01^{\mathrm{d}}$ & $3.65 \pm 1.00^{\mathrm{c}}$ & $3.86 \pm 1.00^{\mathrm{b}}$ & $4.24 \pm 0.01^{\mathrm{a}}$ \\
TA & $1.20 \pm 1.00^{\mathrm{e}}$ & $1.70 \pm 0.01^{\mathrm{d}}$ & $2.23 \pm 1.00^{\mathrm{c}}$ & $2.91 \pm 0.01^{\mathrm{b}}$ & $2.10 \pm 0.01^{\mathrm{b}}$ & $3.16 \pm 1.00^{\mathrm{a}}$ \\
CP & $8.65 \pm 0.02^{\mathrm{f}}$ & $15.42 \pm 0.01^{\mathrm{e}}$ & $22.34 \pm 1.00^{\mathrm{c}}$ & $24.12 \pm 0.01^{\mathrm{b}}$ & $17.10 \pm 0.01^{\mathrm{d}}$ & $29.21 \pm 0.01^{\mathrm{a}}$ \\
CFa & $7.45 \pm 0.01^{\mathrm{f}}$ & $11.00 \pm 1.00^{\mathrm{e}}$ & $19.45 \pm 0.02^{\mathrm{d}}$ & $24.56 \pm 0.02^{\mathrm{c}}$ & $27.20 \pm 0.01^{\mathrm{b}}$ & $30.01 \pm 1.00^{\mathrm{a}}$ \\
CHO & $9.36 \pm 0.01^{\mathrm{f}}$ & $12.00 \pm 1.00^{\mathrm{e}}$ & $14.50 \pm 0.02^{\mathrm{d}}$ & $17.32 \pm 0.01^{\mathrm{c}}$ & $22.01 \pm 1.00^{\mathrm{b}}$ & $27.21 \pm 0.01^{\mathrm{a}}$ \\
\hline
\end{tabular}

Data are presented as mean \pm standard deviation. Means with the different superscript within a row are significantly different $(p<0.05)$. DC: diet composition, MC: moisture content, CFi: crude fiber, TA: total ash, CP: crude protein, CFa: crude fat, CHO: carbohydrate, DT1: commercial diet (control), DT2: 0\% sesame seed meal with 100\% soya bean meal, DT3: 25\% sesame seed meal with 75\% soya bean meal, DT4: $50 \%$ sesame seed meal with 50\% soya bean meal, DT5: 75\% sesame seed meal with 25\% soya bean meal, DT6: $100 \%$ sesame seed meal with $0 \%$ soya bean meal.

Table 4. Proximate composition of fish carcass before to and after the graded levels of the dietary treatment for 12 weeks

\begin{tabular}{lllllll}
\hline \multirow{2}{*}{ DC (\%) } & \multicolumn{5}{c}{ Dietary Treatment } \\
\cline { 2 - 6 } & DT1 & DT2 & DT3 & DT4 & DT5 & DT6 \\
\hline MC & $54.34 \pm 0.01^{\mathrm{a}}$ & $42.23 \pm 0.01^{\mathrm{d}}$ & $42.25 \pm 0.03^{\mathrm{d}}$ & $43.01 \pm 0.04^{\mathrm{b}}$ & $42.56 \pm 0.03^{\mathrm{c}}$ & $42.13 \pm 0.03^{\mathrm{e}}$ \\
CFi & $2.38 \pm 1.01^{\mathrm{a}}$ & $2.27 \pm 0.03^{\mathrm{b}}$ & $2.26 \pm 0.04^{\mathrm{b}}$ & $2.16 \pm 0.03^{\mathrm{c}}$ & $2.15 \pm 0.03^{\mathrm{c}}$ & $2.14 \pm 0.03^{\mathrm{c}}$ \\
TA & $3.50 \pm 0.01^{\mathrm{a}}$ & $3.47 \pm 1.10^{\mathrm{b}}$ & $3.43 \pm 0.02^{\mathrm{b}}$ & $3.34 \pm 0.02^{\mathrm{c}}$ & $3.25 \pm 0.02^{\mathrm{d}}$ & $3.24 \pm 0.04^{\mathrm{d}}$ \\
$\mathrm{CP}$ & $16.25 \pm 1.01^{\mathrm{e}}$ & $16.56 \pm 0.30^{\mathrm{d}}$ & $17.42 \pm 0.02^{\mathrm{c}}$ & $18.11 \pm 0.03^{\mathrm{b}}$ & $18.45 \pm 1.02^{\mathrm{a}}$ & $18.46 \pm 0.04^{\mathrm{a}}$ \\
$\mathrm{CFa}$ & $3.43 \pm 0.02^{\mathrm{e}}$ & $3.51 \pm 0.04^{\mathrm{d}}$ & $3.67 \pm 0.01^{\mathrm{c}}$ & $3.81 \pm 0.03^{\mathrm{b}}$ & $4.08 \pm 0.03^{\mathrm{a}}$ & $4.10 \pm 0.02^{\mathrm{a}}$ \\
CHO & $1.01 \pm 0.01^{\mathrm{a}}$ & $1.04 \pm 0.02^{\mathrm{a}}$ & $1.03 \pm 0.03^{\mathrm{a}}$ & $1.05 \pm 0.02^{\mathrm{a}}$ & $1.05 \pm 0.04^{\mathrm{a}}$ & $1.03 \pm 0.02^{\mathrm{a}}$ \\
\hline
\end{tabular}

Data are presented as mean \pm standard deviation. Means with the different superscript within a row are significantly different $(p<0.05)$. DC: diet composition, MC: moisture content, TA: total ash, CP: crude protein, CFa: crude fat, CHO: carbohydrate, DT1: commercial diet, DT2: 0\% sesame seed meal with 100\% soya bean meal, DT3: 25\% sesame seed meal with 75\% soya bean meal, DT4: $50 \%$ sesame seed meal with 50\% soya bean meal, DT5: 75\% sesame seed meal with 25\% soya bean meal, DT6: 100\% sesame seed meal with 0\% soya bean meal.

Virtually, all the proximate composition of fish carcass fed varying graded levels of experimental dietary groups differed significantly $(\mathrm{p}<0.05)$ as compared to the fish carcass fed a commercial diet (DT1). The protein and crude fat content of fish carcass fed all the dietary treatment was numerically increased significantly $(\mathrm{p}<0.05)$ as compared with that of the control group (DT1). A linear increase of crude fat which associated with an increasing percentage of Sesame indicum levels in the diets was observed in fish carcass across the board (Table 4). The elevated level of protein $(18.46 \%)$ and crude fat $(4.10 \%)$ were observed in carcass fed the diet group (DT6). The fish carcass protein and crude fat treated with experimental diets reflected with the protein and crude fat contents in the respective treatment diets. That is various diets generate different effects on crude protein and fat compositions. This might be due to differences in $S$. indicum seed meal levels in diets. The oily nature of $S$. indicum could possibly reflect the linear increase in the body fat observed in the fish carcass. All fish can regulate amino acid and store excess dietary protein as lipid (Effiong et al., 2019). This finding is in agreement with that of Effiong et al. (2019) that the protein content of $C$. gariepinus increased significantly with increasing dietary protein levels of the diet. Inversely, a significant $(\mathrm{p}>0.05)$ reduction in moisture, crude fiber and total ash contents in fish carcass which associated with increased levels of $S$. indicum diet in various diets were recorded (Table 4). The lower level of moisture $(42.13 \%)$, crude fiber $(2.14 \%)$ and total ash $(3.24 \%)$ were observed in carcass fed DT6. In contrast, the fish carcass moisture (43.01\%), crude fiber $(2.27 \%)$ and total ash (3.47\%) were highest in fish fed DT4 and DT2, respectively (Table 4). The moisture, total ash, crude fiber contents of fish carcass fed tested diets that were not related to increasing levels of $S$. indicum seed meals in the different diets might signify that the whole body compositions are a reflection of treatment diets. The finding is inconsistent with that of Effiong et al. (2019). The macromineral content for both dietary treatments and treated fish carcass were presented in table 5 and 6 , respectively. It reveals significant variation $(p<0.05)$ in all macromineral compositions associated with elevated levels of $S$. indicum diets. The dietary treatments (DT5 and DT6) were significantly richer in all macrominerals than the other diets. 
Elevated calcium (760.7 and $763.6 \mathrm{mg} / 100 \mathrm{~g})$, phosphorus (683.4 and $685.1 \mathrm{mg} / 100 \mathrm{~g})$, sodium (302.4 and $303.4 \mathrm{mg} / 100 \mathrm{~g})$, potassium ( 820.6 and 825 $\mathrm{mg} / 100 \mathrm{~g}$ ) and iron (32.67 and $37.31 \mathrm{mg} / 100 \mathrm{~g}$ ) were noted in dietary treatments (DT5 and DT6) than the other diets involved in this study (Table 5). The result of macrominerals analyzed in treated fish carcass fed graded levels of dietary treatment is presented in table 6 . A significant increase $(p>0.05)$ of all macrominerals numerically, which associated with increased levels of $S$. indicum was confirmed in tested fish carcass fed dietary treatment across the board (Table 6). The fish carcass fed diet containing $100 \%$ of $S$. indicum was richer significantly $(\mathrm{p}>0.005)$ in calcium $(803$ $\mathrm{mg} / 100 \mathrm{~g}$ ), phosphorus $(5023 \mathrm{mg} / 100 \mathrm{~g})$, sodium (492 $\mathrm{mg} / 100 \mathrm{~g})$, potassium $(6313 \mathrm{mg} / 100 \mathrm{~g})$ and iron $(5.12$ $\mathrm{mg} / 100 \mathrm{~g}$ ) than the other treatments involved in this study (Table 6).

Table 5. Macro-mineral determination of the graded composition of the dietary treatments

\begin{tabular}{lllllll}
\hline \multirow{2}{*}{ MC $(\mathbf{m g} / \mathbf{1 0 0 g}$} & \multicolumn{6}{l}{ Dietary treatment } \\
\cline { 2 - 6 } & DT1 & DT2 & DT3 & DT4 & DT5 & DT6 \\
\hline Calcium & $460.7 \pm 0.02^{\mathrm{f}}$ & $580.6 \pm 0.02^{\mathrm{e}}$ & $676.3 \pm 0.03^{\mathrm{d}}$ & $678.3 \pm 0.04^{\mathrm{c}}$ & $760.7 \pm 0.04^{\mathrm{a}}$ & $763.6 \pm 0.03^{\mathrm{a}}$ \\
Phosphorus & $476.3 \pm 0.03^{\mathrm{d}}$ & $620.2 \pm 0.04^{\mathrm{c}}$ & $648.7 \pm 0.03^{\mathrm{b}}$ & $657.3 \pm 0.02^{\mathrm{b}}$ & $683.4 \pm 0.03^{\mathrm{a}}$ & $685.1 \pm 0.04^{\mathrm{a}}$ \\
Sodium & $235.3 \pm 0.03^{\mathrm{e}}$ & $267.2 \pm 0.04^{\mathrm{d}}$ & $272.3 \pm 0.04^{\mathrm{c}}$ & $282.5 \pm 0.02^{\mathrm{b}}$ & $302.4 \pm 0.04^{\mathrm{a}}$ & $303.4 \pm 0.03^{\mathrm{a}}$ \\
Potassium & $654.3 \pm 0.03^{\mathrm{e}}$ & $721.4 \pm 0.03^{\mathrm{d}}$ & $748.6 \pm 0.03^{\mathrm{c}}$ & $760.3 \pm 0.02^{\mathrm{b}}$ & $820.6 \pm 0.03^{\mathrm{a}}$ & $825.5 \pm 0.04^{\mathrm{a}}$ \\
Iron & $16.56 \pm 0.04^{\mathrm{f}}$ & $18.55 \pm 0.02^{\mathrm{e}}$ & $21.34 \pm 0.03^{\mathrm{d}}$ & $26.45 \pm 0.03^{\mathrm{c}}$ & $32.67 \pm 0.03^{\mathrm{b}}$ & $37.31 \pm 0.04^{\mathrm{a}}$ \\
\hline
\end{tabular}

Data are presented as mean \pm standard deviation. Means with the different superscript within a row are significantly different ( $p<0.05)$. MC: macro-mineral composition, DT1: commercial diet, DT2: 0\% sesame seed meal with 100\% soya bean meal, DT3: $25 \%$ sesame seed meal with $75 \%$ soya bean meal, DT4: 50\% sesame seed meal with 50\% soya bean meal, DT5: $75 \%$ sesame seed meal with $25 \%$ soya bean meal, DT6: $100 \%$ sesame seed meal with $0 \%$ soya bean meal.

Table 6. Macro-mineral determination of fish carcass constituent before and after the graded levels of dietary treatment for 12 weeks

\begin{tabular}{lllllll}
\hline \multirow{2}{*}{ MC $(\mathbf{m g} / \mathbf{1 0 0 g})$} & \multicolumn{5}{c}{ After dietary treatments } \\
\cline { 2 - 6 } & DT1 & DT2 & DT3 & DT4 & DT5 & DT6 \\
\hline Calcium & $565 \pm 0.04^{\mathrm{e}}$ & $566 \pm 0.04^{\mathrm{e}}$ & $612 \pm 0.03^{\mathrm{d}}$ & $701 \pm 0.04^{\mathrm{c}}$ & $751 \pm 0.02^{\mathrm{b}}$ & $803 \pm 0.03^{\mathrm{a}}$ \\
Phosphorus & $3165 \pm 0.05^{\mathrm{e}}$ & $3176 \pm 0.05^{\mathrm{e}}$ & $3845 \pm 0.03^{\mathrm{c}}$ & $4102 \pm 0.03^{\mathrm{c}}$ & $4254 \pm 0.04^{\mathrm{b}}$ & $5023 \pm 0.06^{\mathrm{a}}$ \\
Sodium & $236 \pm 0.03^{\mathrm{f}}$ & $243 \pm 0.03^{\mathrm{e}}$ & $252 \pm 0.04^{\mathrm{d}}$ & $321 \pm 0.04^{\mathrm{c}}$ & $430 \pm 0.04^{\mathrm{b}}$ & $492 \pm 0.04^{\mathrm{a}}$ \\
Potassium & $3143 \pm 0.04^{\mathrm{f}}$ & $3150 \pm 0.04^{\mathrm{e}}$ & $3165 \pm 0.04^{\mathrm{d}}$ & $4201 \pm 0.05^{\mathrm{c}}$ & $5102 \pm 0.03^{\mathrm{b}}$ & $6313 \pm 0.05^{\mathrm{a}}$ \\
Iron & $3.02 \pm 0.03^{\mathrm{e}}$ & $3.20 \pm 0.04^{\mathrm{e}}$ & $3.81 \pm 0.05^{\mathrm{c}}$ & $4.03 \pm 0.06^{\mathrm{c}}$ & $4.92 \pm 0.05^{\mathrm{b}}$ & $5.12 \pm 0.06^{\mathrm{a}}$ \\
\hline
\end{tabular}

Data are presented as mean \pm standard deviation. Means with the different superscript within a row are significantly different $(p<0.05)$. MC: macro-mineral composition, DT1: commercial diet, DT2: 0\% sesame seed meal with 100\% soya bean meal, DT3: 25\% sesame seed meal with 75\% soya bean meal, DT4: 50\% sesame seed meal with 50\% soya bean meal, DT5: 75\% sesame seed meal with 25\% soya bean meal, DT6: $100 \%$ sesame seed meal with 0\% soya bean meal.

The elevation of macrominerals of the experimental diets and fish carcass fed various experimental diets compared to the control diet may be reflections of the increasing percentage of $S$. indicum seed meals that possesses improve mineral elements in all diets. It agrees with what reported by Peters et al., (2016) and disagrees with what demonstrated by Olapade and George (2019). Activities of the metabolic processes are mostly protected by mineral elements. Among these are muscle contraction regulation, impulses transmission, the formation of bone, osmotic pressure maintenance, balances of acid-base, glucose absorption, etc (Peters et al., 2016). Peters et al. (2016) and Weaver and Heaney, (2006) reported that calcium is a macronutrient essential to health and wellbeing, which performs a diverse biological functions in the human body. It serves as a second messenger for nearly every biological process, stabilizes much protein and in deficient amounts is associated with a large number of diseases. The results for the growth performance and feed efficiency are shown in table 7. The utilization of diet by the fishes is in the following order: DT6>DT2>DT4>DT3>DT5>DT1 (Table 7). A significant difference $(p<0.05)$ in growth performance and feed efficiency were observed in fish treated with the graded level of diets compared to the fish served with DT1 (control). The weight gains of fish fed different diets are arranged in the following order: DT $6>$ DT $2>$ DT $3>$ DT $4>$ DT $5>$ DT 1 with the DT6 (45.64 mg) recording highest significant value for weight gains (Table 7$)$. A significant $(p<0.05)$ increased in length gain were observed in fish fed DT1 $(1.47 \mathrm{~cm})$, DT5 $(0.98 \mathrm{~cm})$ and DT6 $(0.26 \mathrm{~cm})$ while DT2 $(1.77 \mathrm{~cm})$, DT3 $(1.65 \mathrm{~cm})$ and DT4 $(1.80 \mathrm{~cm})$ were not differed significantly $(\mathrm{p}<0.05)$. A significant difference $(\mathrm{p}<0.05)$ in growth performance and feed efficiency that were observed in fish treated with varying graded levels of diets compared to the fish served with DT1 (control) imply that the treated fish probably utilizes the experimental diets for growth. Also, it could be possible that varying percentage of $S$. indicum seed meals in the experimental diets were utilized well by experimental fish which resulted in good performance of fish as regard their weight and length gain. 
Table 7. Growth performance and nutrient utilization of C. gariepinus fed dietary treatments containing graded levels of S. indicum.

\begin{tabular}{|c|c|c|c|c|c|c|}
\hline \multirow{2}{*}{ GP } & \multicolumn{6}{|c|}{ Dietary treatments } \\
\hline & DT1 & DT2 & DT3 & DT4 & DT5 & DT6 \\
\hline IW $(\mathrm{mg})$ & $54.11 \pm 0.06^{\mathrm{a}}$ & $51.21 \pm 0.04^{\mathrm{c}}$ & $52.32 \pm 0.04^{\mathrm{c}}$ & $50.01 \pm 0.04^{\mathrm{c}}$ & $49.67 \pm 0.02^{\mathrm{d}}$ & $53.01 \pm 0.03^{\mathrm{b}}$ \\
\hline FW (mg) & $72.50 \pm 0.05^{\mathrm{e}}$ & $91.02 \pm 0.03^{\mathrm{b}}$ & $89.32 \pm 0.05^{\mathrm{b}}$ & $83.40 \pm 0.02^{\mathrm{c}}$ & $77.85 \pm 0.05^{\mathrm{d}}$ & $83.56 \pm 0.05^{\mathrm{a}}$ \\
\hline WG (mg) & $18.39 \pm 0.03^{\mathrm{e}}$ & $39.81 \pm 0.02^{\mathrm{a}}$ & $37.01 \pm 0.06^{\mathrm{b}}$ & $33.39 \pm 0.03^{\mathrm{c}}$ & $28.18 \pm 0.01^{\mathrm{d}}$ & $30.64 \pm 0.04^{\mathrm{d}}$ \\
\hline IL $(\mathrm{cm})$ & $7.54 \pm 0.05^{\mathrm{b}}$ & $7.21 \pm 0.02^{\mathrm{b}}$ & $6.78 \pm 0.01^{\mathrm{c}}$ & $6.71 \pm 0.03^{c}$ & $7.35 \pm 0.07^{\mathrm{b}}$ & $8.20 \pm 0.05^{\mathrm{a}}$ \\
\hline $\mathrm{FL}(\mathrm{cm})$ & $9.01 \pm 0.04^{\mathrm{a}}$ & $8.78 \pm 0.02^{\mathrm{a}}$ & $8.65 \pm 0.02^{\mathrm{a}}$ & $8.51 \pm 0.03^{b}$ & $8.33 \pm 0.05^{\mathrm{b}}$ & $8.46 \pm 0.04^{b}$ \\
\hline $\mathrm{LG}(\mathrm{cm})$ & $1.47 \pm 0.03^{b}$ & $1.77 \pm 0.01^{\mathrm{a}}$ & $\begin{array}{c}1.65 \pm 0.04^{\mathrm{a}} \\
\text { FE (\%) }\end{array}$ & $1.80 \pm 0.02^{\mathrm{a}}$ & $0.98 \pm 0.04^{\mathrm{c}}$ & $0.26 \pm 0.03^{c}$ \\
\hline SGR & $21.90 \pm 0.02^{\mathrm{d}}$ & $44.40 \pm 0.04^{\mathrm{b}}$ & $44.06 \pm 0.06^{b}$ & $39.75 \pm 0.07^{\mathrm{c}}$ & $33.55 \pm 0.05^{\mathrm{c}}$ & $54.33 \pm 0.04^{\mathrm{a}}$ \\
\hline PER & $1.13 \pm 0.03^{\mathrm{d}}$ & $2.40 \pm 0.05^{\mathrm{a}}$ & $2.12 \pm 0.05^{\mathrm{b}}$ & $1.84 \pm 0.04^{\mathrm{c}}$ & $1.53 \pm 0.03^{\mathrm{c}}$ & $2.47 \pm 0.03^{\mathrm{a}}$ \\
\hline FI & $1.22 \pm 0.06^{\mathrm{c}}$ & $2.34 \pm 0.01^{\mathrm{a}}$ & $1.95 \pm 0.01^{\mathrm{b}}$ & $2.09 \pm 0.02^{\mathrm{b}}$ & $1.66 \pm 0.02^{\mathrm{c}}$ & $2.85 \pm 0.05^{\mathrm{a}}$ \\
\hline FCR & $0.22 \pm 0.04$ & $0.10 \pm 0.03$ & $0.11 \pm 0.04$ & $0.12 \pm 0.03$ & $0.14 \pm 0.04$ & $0.09 \pm 0.05$ \\
\hline SR & $70.00 \pm 0.04^{\mathrm{c}}$ & $85.00 \pm 0.04^{\mathrm{b}}$ & $95.00 \pm 0.02^{\mathrm{a}}$ & $80.00 \pm 0.06^{\mathrm{c}}$ & $85.00 \pm 0.04^{\mathrm{b}}$ & $80.23 \pm 0.02^{\mathrm{c}}$ \\
\hline
\end{tabular}

Data are presented as mean \pm standard deviation. Means with the different superscript within a row are significantly different ( $p<0.05)$. GP: growth performance, FE: feed efficiency, IW: initial weight, FW: final weight, WG: weight gain, IL: initial length, FL: final length, LG: length gain, SGR: specific growth rate, PER: protein efficiency ratio, FI: feed intake, FCR: feed conversion rate, SR: survival rate, DT1: commercial diet, DT2: $0 \%$ sesame seed meal with 100\% soya bean meal, DT3: 25\% sesame seed meal with 75\% soya bean meal, DT4: $50 \%$ sesame seed meal with 50\% soya bean meal, DT5: $75 \%$ sesame seed meal with $25 \%$ soya bean meal, DT6: 100\% sesame seed meal with 0\% soya bean meal.

The proteins of plants and animal sources have reported in enhancing the growth performance of $C$. gariepinus (Idowu and Afolayan, 2013, Sogbesan et al., 2005, Sogbesan, 2007). Glencross et al. (2007) have demonstrated that the growth of fish is dependence on the ingredients and their percentage inclusion in the formulated feed. Audu et al. (2004) have narrated that source of plant protein together with available feed ingredients could be needed to generate a less costly diet for fish. This trend with the utilization of plant protein in the diets of fish has been confirmed (Olapade and George, 2019). Protein from plant sources with available feed ingredients is been confirmed vital in the formulation of highly nutritious and cost less effective fish diets that have the ability to optimize the $C$. gariepinus production. Promoting less cost production of diets using available food materials in nature with the addition of conventional feeds have been confirmed in aquaculture (Adeogun et al., 1999). Higher significant values were observed for SGR (54.33\%), PER (2.47\%), FI (2.85\%) and SR (80.23\%) as feed utilization in fish fed different diets with $S$. indicum inclusion. However, FCR of fish fed different diets recorded no significance differ from each other (Table 7). Increased significantly, in SGR, PER, FI, FCR, and SR of all experimental diets than the DT1 (control) observed in this study could reflect the good utilization of vary percentage of $S$. indicum in the experimental fish diets. Elevated values of SGR and low value of FCR experienced in this study that is not agreeable with what other researches narrated (Idowu and Afolayan, 2013, Olapade and George, 2019) reflect good quality of diets and their utilization by the experimental fish. It was reported that proper feeding management, condition of the experiment, the system of culture, water maintenance, the adequate balance of amino acids, carbohydrates and good taste of fish diets determine the feed conversion efficiency of fish (Ovie and Ovie, 2007). S. indicum seed meal is a good source of plant protein; however, the ability of fish to make use of proteins is the dependence of fish species (Olapade and George, 2019, Lim and Dominy, 1990). The high values of survival rate recorded in fish fed experimental diets than the control diet signify the low rate of mortality in fish fed the experimental diets compare to the control diet. This could be possibly due to the low level of ammonia and stress generated in the experimental diets compared to the control diet. Hence, the low cost and nutritious aquaculture feeds could be achieved by utilizing the $S$. indicum seed meal. This result was in line with what Idowu and Afolayan (2013) reported but not agreeable with the report of Olapade and Afolayan (2019).

Conclusion: All findings from this study have shown the potential of all experimental diets with varying degrees of beniseed ( $S$. indicum) meal as a supplement to fish meal of $C$. gariepinus fingerlings. However, experimental diets (DT5 and DT6) with 75 and 100\% $S$. indicum inclusion would enhance adequate growth performance and nutrient utilization of $C$. gariepinus and may be used for the development of the product in various food industries.

\section{REFERENCES}

Adeniyan, OO; Ibukun, EO; Ogunbolude, Y; Eseigbe, MI (2013). Effect of Boiling on the Nutritional Composition and Antioxidant Properties of Beniseed (Sesamum indicum L.). Food Sci. Qual. Manage., Vol.11.

Adeogun, OA; Ajana, AM; Ajao, EA (1999). Economic impact assessment of hybrid catfish (Heteroclarias) in Nigeria. N.I.O.M.R. Technical Paper Series, Nigeria, pp: 17. 
AFNOR, (1984). Animal feed calcium determination or assay by Atomic Absorption Spectrometry method. French Standard NF V18-108, September 1984, AFnor, Paris.

AFNOR, (1980). Feed and Animal products: Total phosphorus determination by Spectrophotometric method. French Standard NF V18-108, June 1980, AFnor, Paris.

AFNOR, (1977). Agricultural products and feed resources Nitrogen assay for crude protein determination, crude ash, fat and moisture assays. French Standard NF V18-100, 101, 104 and 108, October 1977, AFnor, Paris.

Alatise, PS; Ogundele, O; Eyo, AA; Oludunjoye, F (2006). Evaluation of Different Soybean-Based Diets on Growth and Nutrient Utilization of Heterobranchus longifilis in Aquaria Tanks. Proceedings of the Fisheries Society of Nigeria (FISON) Conference held at the University of Calabar, Calabar, Nigeria, 13-17 November, pp. $255-262$

Alobo, AP; (2001). Effect of sesame seed flour on millet biscuit characteristics. P Food Human Nutr., 2001;56(2):195-202

AOAC, (2004). Association of Official Analytical Chemists. Official Methods of Analysis. 18th ed., Gaithersburg, MD, p. 240.

Audu, PA; Oniye, SJ; Okechukwu, PU (2004). Helminth parasites of domesticated pigeons (Columba livia domestica) in Zaria, Nigeria. J. Pest Dis. Vector Manage. 5: 356-360.

Ayoola, AA (2010). Replacement of Fishmeal with Alternative Protein Sources in Aquaculture Diets. $A$ thesis submitted to the Graduate Faculty of North Carolina State University in partial fulfillment of the requirements for the Degree of Master of Science

Conney, RV; Custer, LT; Okinaka, L (2001). Effects of dietary sesame seeds on plasma tocopherol levels. Nutr. Cancer. 39(1):66-71.

Effiong, MU; Akpan, AW; Ayotunde, EO (2014). Effects of Feeding Different Dietary protein levels on Reproductive Biology of African Mud Catfish (Clarias gariepinus). J. Aquatic Sci., 29 (1b): 113-124.
Effiong, MU; Akpan, AW; Essien-Ibok, MA (2019). Effects of Dietary Protein Levels on Proximate, Haematological and Leukocyte Compositions of Clarias gariepinus. J. Appl. Sci. Environ. Manage. Vol. 23 (11), p. 2065-2069.

Fagbenro, OA; Davies, SJ (2000). Use of oilseed meals as fishmeal replacers in tilapia diets. Proceedings of the 5th International Symposium on Tilapia in Aquaculture, September 3-6, 2000, Brazil.

Fagbenro, OA (1999). Equi-protein replacement of soybean meal with winged bean meals in diets for the African clariid catfish, Clarias gariepinus (Burchell). J. Aqucult. Trop., 14. P. 93-99.

Glencross, BD; Booth, M; Allan, GL (2007). A feed is only as good as its ingredients: A review of ingredient evaluation strategies for aquaculture feeds. Aquacult. Nutr., 13: 17-34.

Garbia, HAA; Shehata, AAY; Shahidi, F (2000). Effect of Processing on oxidative stability and lipid classes of Sesame oil. Food Res. Intl., 33(5):331-340.

Idowu, EO; Afolayan, EB (2013). The Effects of Supplementing of Fish Meal with Maggots at Varying Levels in the Diet of Clarias gariepinus. Int. Arch. App. Sci. Technol. Vol 4 [4], p.41-47.

Ihekoronye, ME; Ngoddy, BN (1985). Chemistry of Oil Extraction. 5th ed. Punglo Press; p. 21-56.

Jimoh, WA; Fagbenro, OA; deparusi, EOA (2014). Response of African catfish, Clarias gariepinus (Burchell 1822), fingerlings fed diets containing differently timed wet-heat-treated sesame (Sesamum indicum) seedmeal. Agric. Sci., 5: 1159-1171.

Keke, IR; Anene, A (2011). Length-Weight Relationship and Fecundity of Clarias gariepinus from River Niger. J. Aquatic Sci., 26 (1): 1-7.

Kumar, V; Makkar, HPS; Becker, K (2011). Detoxified Jatropha curcas kernel meal as a dietary protein source: Growth performance, nutrient utilization and digestive enzymes in common carp, Cyprinus carpio fingerlings. Aquacult. Nutr., 7: 313-326.

Lim, C; Dominy, W (1990). Evaluation of soybean meal as a replacement for marine animal protein 
in diets for shrimp (Penaeus vannamei). Aquacult., 87: 53-63.

Olapade, OJ; George, PQ (2019). Nutritional Evaluation of Defatted Groundnut Cake meal with Amino acid as Protein Supplement in African Catfish (Clarias gariepinus Burchell, 1822) Juveniles Diet. J. Fish and Aquatic Sci., p. 7.14 .

Ovie, SO; Ovie, SI (2007). The effect of replacing fish meal with $10 \%$ of groundnut cake in the diets of H. longifilis on its growth, food conversion and survival. J. Appl. Sci. Environ. Manage. 11: 8790

Peters, H; Gloria, FN; Ikpeme, CE (2016). Nutritional evaluation of breadfruit and beniseed composite flours. MOJ Food Process Technol., 2(6), p. 194 199

Ragone, D (1997). Breadfruit (Artocarpu saltilis) (Parkinson) Forsberg. Promoting the conservation and use of underutilized and neglected crops.
Sogbesan, AO; Ajounu, ND; Madu, CT; Omojowo, FS; Ugwumba, AAA (2005). Growth response, feed conversion rate and cost benefit of hybrid catfish fed maggot meal-based diet in outdoor tank, 2004 FISON conference proceeding, Pp.816.

Sogbesan, AO (2007). Performance of Heterobranchus longifilis fingerlings fed maggot based diets in mini flow through system. 2006 FISON conference proceeding, Pp. 41.

Uaboi, PU; Sobande, AO; Okolie, PN (2008). Proximate composition of whole dehulled and fermented beniseed (sesame indicum) with associated bacteria species. Nig. Food J. 26(1):16.

Weaver, CM; Heaney, RP (2006). Calcium in Human Health. USA.

Zar, JH (1996). Biostatistical Analysis. 3rd Edition, Prentice Hall Inc., Englewood Cliffs, New Jersey, USA 